ELORE (ISSN 1456-3010), vol. 20 - 2/2013.

Julkaisija: Suomen Kansantietouden Tutkijain Seura ry.

[http://www.elore.fi/arkisto/2_13/granbom-herranen.pdf]

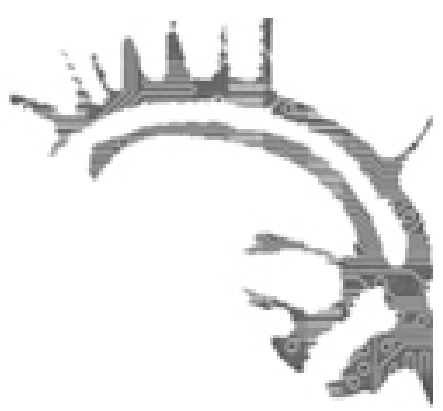

\title{
KIRJA-ARVIO
}

\section{VERKOSTA JA SOLMUISTA}

\author{
Liisa Granbom-Herranen
}

LAAKSONEN, SALLA-MAARIA \& MATIKAINEN, JANNE \& TIKKA, MINTTU (TOIM.) 2013: Otteita verkosta. Verkon ja sosiaalisen median tutkimusmenetelmät. Tampere: Vastapaino. 377 sivua.

Verkko kiinnostaa sekä suurta yleisöä että tutkijoita osittain samoista ja osittain toisistaan poikkeavista syistä. Keskeistä on verkossa välitettävän tiedon käyttö sekä sen kautta tapahtuva yhteydenpito. Erona on se, että tutkijoiden kiinnostus kohdistuu myös ilmiöön ja sen myötä muodostuneisiin uusiin käytänteisiin - verkosta voidaan puhua monissa merkityksissä ja yhteyksissä. Sain vinkin kirjasta internet-aineistoja käyttävältä turkulaiselta tutkijakollegalta evästyksellä "mielenkiintoinen" ja "tarpeeseen”. Tämä kannusti tarttumaan kirjaan.

Takakansi esittelee teoksen olevan "ensimmäinen suomenkielinen menetelmäopas verkkotutkimusta tekeville". Verkko, verkosto, verkostossa tutkiminen, verkostotutkimus ovat teoksen nimen mukaisesti keskeisiä. Voi kuitenkin olla, että lukija jää vielä kirjan luettuaankin pohtimaan mistä on kyse, kun puhutaan verkkotutkimuksesta. Onko kyseessä verkkotutkimus, tutkimus verkossa vai verkon tutkimus? Siihen teos ei anna vastausta - eikä se ilmeisesti ole ollut tarkoituskaan. Johtopäätökset jäävät lukijan tehtäväksi. Kirja tarjoaa yleiskatsauksen siitä, mitä verkkotutkimus on, on ollut, saattaa olla ja mahdollisesti on tulevaisuudessa. Samalla teos antaa lukijalle näkemyksen siitä, 
että vaikka puhutaan verkosta, eivät kaikki tutkijat puhu samasta asiasta. Jo otsikoissa on verkkoa vilisemällä: verkko, verkkotutkimus, verkkokysely, verkkolomake, verkkokyselytutkimus, verkkokyselylomake, verkosto, verkkokeskustelu, verkostoanalyysi, verkkomedia, verkkopalvelut. Lisäksi teoksessa on runsaasti synonyymeja tai liki-synonyymeja sekä verkolle että sähköiseen verkkoon liittyville käsitteille. Kiitettävää on kirjan lopussa oleva peräti 13-sivuinen sanasto, josta myös monet otsikoissa mainituista termeistä löytyvät.

Teoksen tavoitteeksi määritellään verkkotutkimuksen metodologian käsittely, eettisten ja kulttuuristen lähtökohtien tarkastelu, verkkokyselyiden tekemisen ohjaus, sekä verkkokeskustelujen että verkkoyhteisöjen tutkimuksellisiin kysymyksiin paneutuminen, verkon historian hahmottaminen ja lisäksi suurten aineistojen tutkimuksellisten mahdollisuuksien hyödyntämisen esittely. Tavoite on kunnianhimoinen ja sen rajaus olisi saattanut jämäköittää teoksen antia.

\section{VAIHTELEVA ARTIKKELIKOKOELMA}

Teoksella on 25 kirjoittajaa, joista jotkut ovat osallistuneet useammankin artikkelin kirjoittamiseen. Monet kirjoittajista ovat työsuhteessa olevia tohtoriopiskelijoita, ja teos lienee täten myös avaus lähitulevaisuudessa toteutettavien tutkimusten aiheisiin, -kenttään ja -menetelmiin.

Artikkelien kokonaismäärä on 16 , joten ymmärrettävästi niiden taso vaihtelee. Kaikissa artikkelissa voi havaita toimittajien esipuheessa mainitseman innostuksen aiheesta. Joistakin artikkeleista lukijan on helppo saada selko aiheen vieraudesta huolimatta, kuten Jukka Huhtamäen ja Olli Parviaisen verkostoanalyysia sosiaalisen median tutkimuksessa käsittelevästä artikkelista. Tämä sekä Antti Ukkosen suuriin aineistoihin paneutuva artikkeli ovat sitä, mitä lukija tämänkaltaiselta opastavaksi tarkoitetulta teokselta odottaa. Kokoelmassa on myös artikkeleita, joiden kohdalla lukija pohtii, mitä niillä on pyritty sanomaan.

Artikkeleissa on käytetty runsaasti esimerkkejä. Jotkut esimerkkitapauksista ovat jopa rasittavan yksityiskohtaisia, ja siten kiinnostavat lähinnä samankaltaista aineistoa tai menetelmää käyttäviä. Esimerkkeinä käsiteltävien tutkimusaineistojen aihepiirit vaihtelevat anoreksiasta tsunamiin ja laajuudeltaan yhden ihmisen kokemuksesta laajan tapahtuman tarkasteluun. Teos toiminee parhaiten luettaessa sitä omaan tutkimusintressiin soveltuvin osin.

\section{"VERKKO EI TARJOA OIKOTIETÄ TUTKIMUKSEN TEKEMISEEN"}

Teos on jaettu viiteen päälukuun, joissa kussakin on kolme tai neljä artikkelia. Pääosin artikkelit ovat usean kirjoittajan yhteistyötä. Esipuheessa kokoelman toimittajat mainitsevat kysymyksiä, joihin teos pyrkii vastaamaan. Tällaisia ovat vanhojen menetelmien käyttökelpoisuus uudessa kontekstissa, uusien menetelmien tarve sekä verkosta kerättävän aineiston erityispiirteet. Teos pyrkii käsittelemään verkkoon liittyvää tutkimusta 
varsin kattavasti. Monet artikkeleista alkavat lauseella internetin yleistymisen myötä lisääntyneestä tutkimustarpeesta: "On uusi [..]", ” Tähän on tarvetta [..]”, ” [..] ei ole olemassa minkäänlaisia yksiselitteisiä ohjeita [..]”. Tällaiset kommentit ovat varmasti aiheellisia itsenäisessä artikkelissa, mutta toistuessaan artikkelikokoelmassa liki jokaisen artikkelin alussa lausahdukset menettävät merkitystään, sillä uutuuden ajatus on esitetty jo esipuheessa. Viittaus tietoverkon uutuuteen on kuitenkin lähinnä klisee; nykyisen www-muodon yhteinen tietoverkko, internet, sai alkunsa jo yli 20 vuotta sitten, kuten teoksen sivulla 196 todetaan.

Ensimmäisessä luvussa keskiöön on nostettu kysymys, tarvitaanko verkon ja sosiaalisen median tutkimiseen uusia tutkimusmenetelmiä. Kysymys on selkeä ja mielenkiintoinen, mutta vastausta tähän kirja ei anna. Aineistot tai menetelmät eivät eroa haastateltavan kanssa vuorovaikutuksessa toteutettavista tutkimuksista. Vastausta vaille jäävät edelleen verkkoon liittyvän tutkimuksen erityispiirteet esimerkiksi materiaalin, menetelmän, tavoitteen ja tuloksen suhteen. Läpi teoksen toistuu myös huomautus "ei-verkossa". Juuri tähän ei-verkon ja verkon välisen suhteen tarkasteluun olisin toivonut selkeämpää otetta: mikä on ero, mitä verkko erityisesti edellyttää?

Teoksen alkuosa keskittyy yleiseen tasoon, josta siirrytään lomaketietouden kautta ensin kulttuurin- ja sitten vuorovaikutusverkostojen tutkimukseen. Viimeisessä osassa teos keskittyy teknologioiden ja käyttäjien kohtaamiseen. Tässä osiossa erityisesti Pekka Räsäsen ja Outi Sarpilan sekä Arto Selkälän artikkelit tuovat erinomaisesti esille uusien verkkoaineistojen ja varhaisempien keruiden aineistojen käsittelyn eroavaisuuksia. Nämä artikkelit on kirjoitettu tehokkaasti ja selkeästi kuvittelematta jokaista lukijaa asiantuntijaksi.

\section{ILMIÖKSI ILMIÖSSÄ}

Artikkelikokoelma on itsessään verkkoilmiö. Kirja on saanut blogeissa ja kommenteissa julkisuutta. Teoksesta voi tykätä verkossa, ja sille on omat sivunsa sekä Facebookissa että Twitterissä. "Otteitaverkosta.fi kehittyy jatkossa verkkotutkimuksen linkkivarannoksi, jossa myös julkaistaan kirjan artikkeleihin liittyviä tausta-aineistoja" (Otteitaverkosta.fi).

Kirjan mahdollinen yhtenäisyyttä korostava jäsentely ei oikein avaudu lukijalle. Kenties selkeyttä olisi lisännyt Salla-Maaria Laaksosen, Janne Matikaisen ja Minttu Tikan artikkelissaan tarjoama jaottelu verkosta välineenä tai ilmiönä. Kirjan jäsentelyn selkeyttä olisi voinut lisätä hyödyntämällä Salla-Maaria Laaksosen ja Janne Matikaisen artikkelissa esitettyä synkroninen - asynkroninen -asetelmaa. Lähes jokaisen artikkelin lopussa on löydettävissä jonkinlainen muisti- tai vinkkilista. Näistä kommenteista olisi teoksen yhtenäisyyttä korostaen voinut koostaa yhteisen osion joko teoksen tai kunkin osan päätteeksi.

Lukijana kaipasin jonkinasteista yhteistä sanastoa. Esimerkiksi lähtökohtana "monitieteinen" ei sinällään anna tietoa, kuinka teos käsittää monitieteisyyden ja poikkitieteisyyden eron. Onko tavoitteena monen tieteenalan paradigmoja käyttävä lähestymistapa, kuten Katja Huumon, Lea Laitisen ja Outi Paloposken $(2004,12)$ tavassa 
määritellä monitieteisyys? Ehkä tämä on vaikuttanut siihen, että joissakin artikkeleissa käsitteistöä pyritään selventämään paikoitellen jopa turhan yksinkertaisesti, kuten "interaktio eli vuorovaikutus". Tämä varsinkin, kun muistetaan teoksen keskeiseksi kohderyhmäksi määritellyn tutkimusta ja opinnäytteitä tekevät. Kirja on kooste kaikesta siitä, mitä liitetään verkkoon aineistona, menetelmänä, sisältönä ja kontekstina. Kirjaa ei liene tarkoitettukaan kerralla luettavaksi, vaan omaan ongelmaan soveltaen.

\section{KirjallisuUs}

HUUMO, KATJA \& LAITINEN, LEA \& PALOPOSKI, OUTI 2004: Alkusanat. Huumo, Katja \& Laitinen, Lea \& Paloposki, Outi (toim.), Yhteistä kieltä tekemässä. Näkökulmia suomen kirjakielen kehitykseen 1800 luvulla. Helsinki: SKS.

OTTEITAVERKOSTA.FI. [online]. <http://www.otteitaverkosta.fi> [5.8.2013.]

Kasvatustieteen tohtori ja filosofian maisteri Liisa Granbom-Herranen toimii Suomen Akatemian tutkijatohtorina Jyväskylän yliopistossa kasvatustieteiden laitoksella. 